\section{Cardinal Temperatures and Thermal Time for Seed Germination of Brunonia australis (Goodeniaceae) and Calandrinia sp. (Portulacaceae)}

\author{
Robyn L. Cave ${ }^{1}$ \\ The University of Queensland, School of Agriculture and Food Sciences, \\ Gatton, Queensland 4343, Australia \\ Colin J. Birch \\ Tasmanian Institute of Agricultural Research, University of Tasmania, \\ Burnie, Tasmania 7320, Australia
}

\section{Graeme L. Hammer \\ The University of Queensland, School of Agriculture and Food Sciences, St. Lucia, Queensland 4072, Australia}

John E. Erwin

Department of Horticultural Science, University of Minnesota, St. Paul, MN 55108

\section{Margaret E. Johnston ${ }^{2}$ \\ The University of Queensland, School of Agriculture and Food Sciences, Gatton, Queensland 4343, Australia}

Additional index words. Australian native, floriculture, seed propagation, scheduling, ornamental, degree-day

\begin{abstract}
Seed germination of Brunonia australis Sm. ex R.Br. and Calandrinia sp. (Mt. Clere: not yet fully classified) was investigated using a thermogradient plate set at different constant temperatures to determine seed propagation requirements of these potential floriculture species. Germination responses were tested at 3, 7, 11, 15, 18, 22, 25, 29, 34, and $38^{\circ} \mathrm{C}$. Germination data were modeled using the cumulative distribution function of the inverse normal, which provides information on lag, rate, and maximum seed germination for each temperature regime. To determine cardinal temperatures, the reciprocal time to median germination $\left(1 / t_{50}\right)$ and percentage germination per day were calculated and regressed against temperature. Base temperature estimates for $B$. australis were 4.9 and $5.5^{\circ} \mathrm{C}$ and optimum temperatures were 21.4 and $21.9^{\circ} \mathrm{C}$, whereas maximum temperatures were 35.9 and $103.5^{\circ} \mathrm{C}$, with the latter being clearly overestimated using the $1 / t_{50}$ index. Base temperatures for Calandrinia sp. were 5.8 and $7.9^{\circ} \mathrm{C}$, whereas optimum and maximum temperature estimates of 22.5 and $42.7^{\circ} \mathrm{C}$, respectively, were reported using the percentage germination per day index. Maximum seed germination of 0.8 to 0.9 , expressed as the probability of a seed germinating, occurred at 11 to $25^{\circ} \mathrm{C}$ for $\mathrm{B}$. australis, whereas maximum germination for Calandrinia sp. was 0.5 to 0.7 at 18 to $25^{\circ} \mathrm{C}$. Thermal time, the accumulation of daily mean temperate above a base temperature, was calculated for different germination percentages. Estimates of thermal time $\left({ }^{\circ} \mathrm{Cd}\right.$ ) for $50 \%$ seed germination were 54 and $90{ }^{\circ} \mathrm{Cd}$ for $\mathrm{B}$. australis and Calandrinia sp., respectively.
\end{abstract}

\footnotetext{
Received for publication 27 Dec. 2010. Accepted for publication 3 Mar. 2011.

We gratefully acknowledge funding from The Centre for Native Floriculture, The University of Queensland, and Rural Industries Research and Development Corporation. We thank Allan Lisle for support with statistical analyses, Victor Robertson and Ross Bourne for technical assistance, and Doug George and Santi Krisantini for their valuable comments on the manuscript.

${ }^{1}$ Graduate student, The Centre for Native Floriculture.

${ }^{2}$ To whom reprint requests should be addressed; e-mailm.johnston@uq.edu.au.
}

Brunonia australis and Calandrinia $\mathrm{sp}$ are Australian native herbs with potential for commercialization as flowering potted plants or bedding plants. Both species are ideally grown as annuals and, like many traditional short-lived garden plants, are most economically propagated by seed. Nursery managers often schedule plant production for peak market periods outside the natural growing season. Therefore, it is necessary to understand factors that impact propagation as well as growth and development to facilitate proAlthough Roche et al. (1997) investigated the duction protocols for year-round cultivation. effects of smoke on seed dormancy of $B$. australis, this is the first study to investigate the effect of different constant temperatures on seed germination of this species and of Calandrinia sp.

$B$. australis flowers naturally in spring to early summer from September to December, producing blue inflorescences on long slender stalks (Carolin, 1992; Stanley and Ross, 1986). This species is widespread throughout Australia, including southern Queensland, where average minimum winter temperatures are $\approx 5$ to $7{ }^{\circ} \mathrm{C}$ and maximum temperatures are 19 to $21{ }^{\circ} \mathrm{C}$ (Bureau of Meteorology, 2010a). In spring and early summer, minimum temperatures are $\approx 10$ to $20{ }^{\circ} \mathrm{C}$ with daytime temperatures reaching 25 to $34{ }^{\circ} \mathrm{C}$. Calandrinia sp. is a drought-tolerant succulent (Harrison et al., 2009) with large pink flowers. There are only two known collections of this species, and both occur in the Gascoyne region of Western Australia (F. Obbens, personal communication). There are no published reports on growth and flowering of this species in its natural habitat, but other species within this genus usually flower in spring (September to November). The Gascoyne region has an arid climate where the average minimum temperature during winter is $\approx 9^{\circ} \mathrm{C}$ and the maximum temperature is 21 to $23{ }^{\circ} \mathrm{C}$ (Bureau of Meteorology, 2010b). In spring, minimum temperatures are $\approx 12$ to $19^{\circ} \mathrm{C}$, and maximum temperatures range from 27 to $34{ }^{\circ} \mathrm{C}$.

Temperature is an important regulator of seed germination and is thought to be perceived within seed membranes (Mayer and Marbach, 1981). Temperatures that promote seed germination of many species typically correspond to natural environmental conditions, such as adequate soil moisture, that are conducive to seedling survival (Bell, 1999; Bell et al., 1993). Most seeds will germinate at $\approx 20$ to $24{ }^{\circ} \mathrm{C}$ (Mayer and PoljakoffMayber, 1989). Imbibed seeds may not germinate at low temperatures, but in some species, cold stratification at $\approx 0$ to $10^{\circ} \mathrm{C}$ is required to break dormancy (Baskin and Baskin, 2004; Mayer and Poljakoff-Mayber, 1989). High temperatures usually induce or maintain dormancy of imbibed seeds, but seed death may occur as observed in several Australian species (Bell et al., 1993; Bellairs and Bell, 1990).

Germination rate indices are typically used to quantify cardinal temperatures for seed germination and include reciprocal time to median germination and percentage germination per day. Linear regression of a germination rate function versus sub- and supraoptimal temperatures and extrapolation of the same lines to the x-axis (intersect) are usually used to estimate minimum and maximum temperatures (Holt and Orcutt, 1996). The point where the two lines intersect defines the estimated optimum temperature at which germination is typically more rapid and the percentage germination greater. Usually, more than one germination rate index is used, and the adequacy of fit statistically compared to provide the most accurate method for estimating cardinal temperatures. 
A robust estimate of the base (minimum) temperature for germination, at which development stops, is an essential requirement for calculating thermal time (Slafer and Savin, 1991). Thermal time, defined as the accumulation of daily mean temperature above a base temperature, is widely used in scheduling ornamental crop production. The approach can be more useful for predicting plant development stages than calendar date when temperatures for germination, or other development stages, are outside the experimental data range (Slafer and Savin, 1991).

The objectives of the study were to investigate seed germination responses of $B$. australis and Calandrinia sp. at different constant substrate temperatures to establish base, optimum, and maximum temperatures and to determine thermal time requirements. Two germination rate indices, used to provide estimates of cardinal temperatures, were compared. This information will be valuable for scheduling year-round production of these seed-propagated species and for providing insight into germination responses in the plant's natural habitat.

\section{Materials and Methods}

Seed source and experimental procedures. Seeds of $B$. australis were collected from a wild population in southern Queensland (lat. $27^{\circ} 54.905^{\prime} \mathrm{S}$, long. $149^{\circ} 51.139^{\prime} \mathrm{E}$ ) in Oct. 2003. Calandrinia sp. seeds were collected from plants grown at The University of Queensland, Gatton Campus (UQG) in 2004. Both species were stored at $10{ }^{\circ} \mathrm{C}$ in a specialized seed store at UQG. Undamaged seeds were selected and surface-sterilized in $2 \mathrm{~g} \cdot \mathrm{L}^{-1}$ chlorine with a drop of non-ionic wetting agent (Agral; ICI Crop Care, Australia) for $10 \mathrm{~min}$ and then triple-rinsed with deionized water. Seeds were then transferred to $65-\mathrm{mm}$ diameter, $10-\mathrm{mm}$ plastic petri dishes lined with two sheets of filter paper (Whatman No. 1) moistened with deionized water.

Germination responses were measured at $3,7,11,15,18,22,25,29,34$, and $38^{\circ} \mathrm{C}$ on a one-way thermogradient plate with 10 insulated chambers (Lindner and May Pty. Ltd., Windsor, Brisbane, Australia). The table surface temperature for each chamber was logged every $10 \mathrm{~min}$ using a standard thermistor probe (PB-5001) coupled to a data logger (Tinytag; Hastings data loggers, Port Macquarie, New South Wales, Australia). Variation from the set point was \pm 0.3 to $0.9^{\circ} \mathrm{C}$. The temperature at the table surface was not considered different from the temperature of the substrate (moist filter paper) based on a preliminary study. Three petri dishes, each containing 20 seeds, were placed across the width of the table at each temperature division for both species (total of 30 dishes per species). Seeds of B. australis were germinated in the dark by wrapping the petri dishes in aluminium foil and seeds of Calandrinia sp. were germinated under a 16-h daylength as per requirements identified in a preliminary study. Light intensity of less than
$10 \mu \mathrm{mol} \cdot \mathrm{m}^{-2} \cdot \mathrm{s}^{-1}$ was provided by $40-\mathrm{W}$ widespectrum florescent lamps (Gro-Lux; Osram Sylvania, Danvers, MA).

Seeds were observed up to four times daily at the beginning of the experiment when germination was rapid and then gradually reduced to once a day until all seeds had germinated or no additional germination had occurred for $5 \mathrm{~d}$. Germinated seeds were removed from the petri dish when the radicle or cotyledons (Calandrinia sp.) were $2 \mathrm{~mm}$ or greater. Seeds that failed to germinate within $31 \pm 0.5 \mathrm{~d}$ after sowing were transferred to a temperature-controlled room at $18 \pm 1.0^{\circ} \mathrm{C}$. Seeds of Calandrinia sp. were illuminated with a light intensity of $16 \mu \mathrm{mol} \cdot \mathrm{m}^{-2} \cdot \mathrm{s}^{-1}$ for $16 \mathrm{~h} \cdot \mathrm{d}^{-1}$ and seeds of $B$. australis were germinated under darkness. Seeds were assessed periodically for germination. After $\approx 25 \mathrm{~d}$, when no further germination was observed, seeds were cut using a scalpel to assess viability and soft or discolored seeds were considered unviable. The experiment was repeated once over time during 2008 (Run 1 and Run 2).

Data analysis. Data collected from the three petri dishes, for each temperature regime, were pooled because they were not considered different from one another. Germination data were modeled using the cumulative distribution function of the inverse normal, also known as the inverse Gaussian distribution. O'Neil et al. (2004) reported that the inverse normal distribution was a natural distribution for time to germination and included parameters to measure lag, rate, and maximum seed germination. The probability of a seed germinating, time ( $t$, days) taken for a given percentage $(G)$ of the seed population to germinate, and delay in seed germination were calculated for each temperature $(T)$ regime. The effect of temperature on germination rate was investigated using two germination rate indices. The reciprocal of days taken to reach a given percentage of total seed germination $\left(1 / t_{G}\right)$ was calculated as:

$$
1 / t_{G}=\frac{1}{\text { days to } G}
$$

where $G$ is a given percentage of the total seed population, e.g., $10 \%, 20 \%, 30 \%$, etc., adapted from Holt and Orcutt (1996). Percentage seed germination per day was calculated as:

$$
\begin{aligned}
& \% \text { germination } / \text { day } \\
& =\frac{\% \text { germination }}{\text { days to complete germination }}
\end{aligned}
$$

where the last day on which any germination occurred was used as the denominator (Holt
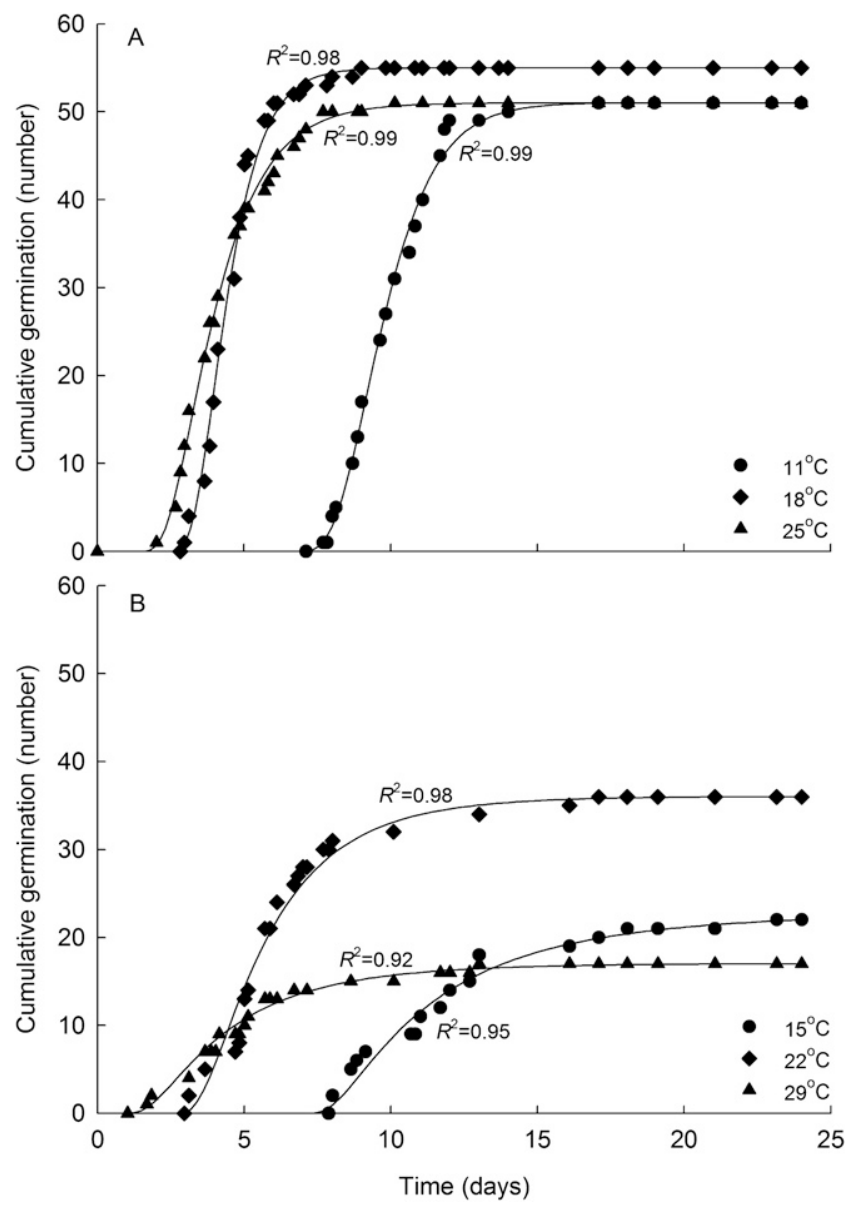

Fig. 1. Adequacy of fit $\left(R^{2}\right)$ of the inverse normal distribution to observed data for cumulative seed germination of B. australis (A) and Calandrinia sp. (B) at three contrasting substrate temperatures. A total of 60 seeds was used for each temperature regime and species. The experiment was repeated once over time and data from the first run (Run 1) are shown. 
and Orcutt, 1996). Data from Run 1 and Run 2 were analyzed using the GLM procedure in SAS Version 9.1 (SAS Institute Inc., Cary, NC). Estimates of base $\left(T_{\mathrm{b}}\right)$, optimum $\left(T_{\mathrm{o}}\right)$, and maximum $\left(T_{\mathrm{m}}\right)$ temperature were obtained by regression of least-square adjusted means (LSMEANS) for reciprocal time to median germination $\left(1 / t_{50}\right)$ and percentage germination per day, against temperature, using SigmaPlot Version 10 (Systat Software Inc., Chicago, IL). Linear and broken linear functions were used to describe the relationship between germination rate and temperature. The broken linear function was in the form of:

$$
R=\left\{\begin{array}{l}
\frac{R_{\mathrm{opt}}}{T_{\mathrm{o}}-T_{\mathrm{b}}}\left(T-T_{\mathrm{b}}\right), \text { if } T_{\mathrm{b}}<T<T_{\mathrm{o}} \\
\frac{R_{\mathrm{opt}}}{T_{\mathrm{m}}-T_{\mathrm{o}}}\left(T_{\mathrm{m}}-T\right), \text { if } T_{\mathrm{o}}<T<T_{\mathrm{m}}
\end{array}\right.
$$

where $R$ is the germination rate, $R_{\mathrm{opt}}$ the optimum germination rate, $T$ the temperature, $T_{\mathrm{b}}$ the base temperature, $T_{\mathrm{o}}$ the optimum temperature, and $T_{\mathrm{m}}$ the maximum temperature. Thermal times $\left({ }^{\circ} \mathrm{Cd}\right)$ of $G$ were calculated using the mean minus base method and a common base temperature (mean value of $T_{\mathrm{b}}$ estimates for all values of $G$ ) and equations reported by GarciaHuidobro et al. (1982). All data were included in analyses, unless stated otherwise. All values result from tests on single seed lots of both species.

\section{Results}

Adequacy of fit of the inverse normal distribution. The adequacy of fit $\left(R^{2}\right)$ of the inverse normal distribution at different substrate temperatures for cumulative seed germination of $B$. australis and Calandrinia sp. is demonstrated in Figures $1 \mathrm{~A}$ and $\mathrm{B}$, respectively. Values of $R^{2}$ were greater than 0.90 for all temperature regimes, except at 7 and $11{ }^{\circ} \mathrm{C}$ (lowest temperature that germination occurred), where values of $\approx 0.55$ and 0.80 were reported for $B$. australis and Calandrinia sp., respectively.

Probability of a seed germinating. $B$. australis showed a higher (greater than 0.75 ) probability of seed germination at $\approx 11$ to $25{ }^{\circ} \mathrm{C}$, whereas Calandrinia sp. showed germination of greater than 0.5 at $\approx 18$ to $25^{\circ} \mathrm{C}$ (Fig. 2A-B). While no seeds germinated at the lowest temperature tested $\left(3{ }^{\circ} \mathrm{C}\right)$ for either species, some germination was observed at 7 and $11{ }^{\circ} \mathrm{C}$ for $B$. australis and Calandrinia sp., respectively. At the highest temperature regimes of 34 and $38{ }^{\circ} \mathrm{C}$, germination of Calandrinia $\mathrm{sp}$. was reduced to $\approx 0.14$ and inhibited for B. australis.

When non-germinated seeds of $B$. australis were transferred to $18{ }^{\circ} \mathrm{C}, 58 \%$ germination was observed for seeds removed from $3{ }^{\circ} \mathrm{C}$, whereas $2 \%$ and $7 \%$ germination were obtained for seeds previously incubated at 34 and $38^{\circ} \mathrm{C}$, respectively. Similarly, seed of Calandrinia sp. transferred to $18^{\circ} \mathrm{C}$ after incubation at $3{ }^{\circ} \mathrm{C}$ showed higher germination of $40 \%$, whereas only $12 \%$ of seeds germinated after incubation at $7{ }^{\circ} \mathrm{C}$ and $2 \%$ or less of seeds germinated when removed from

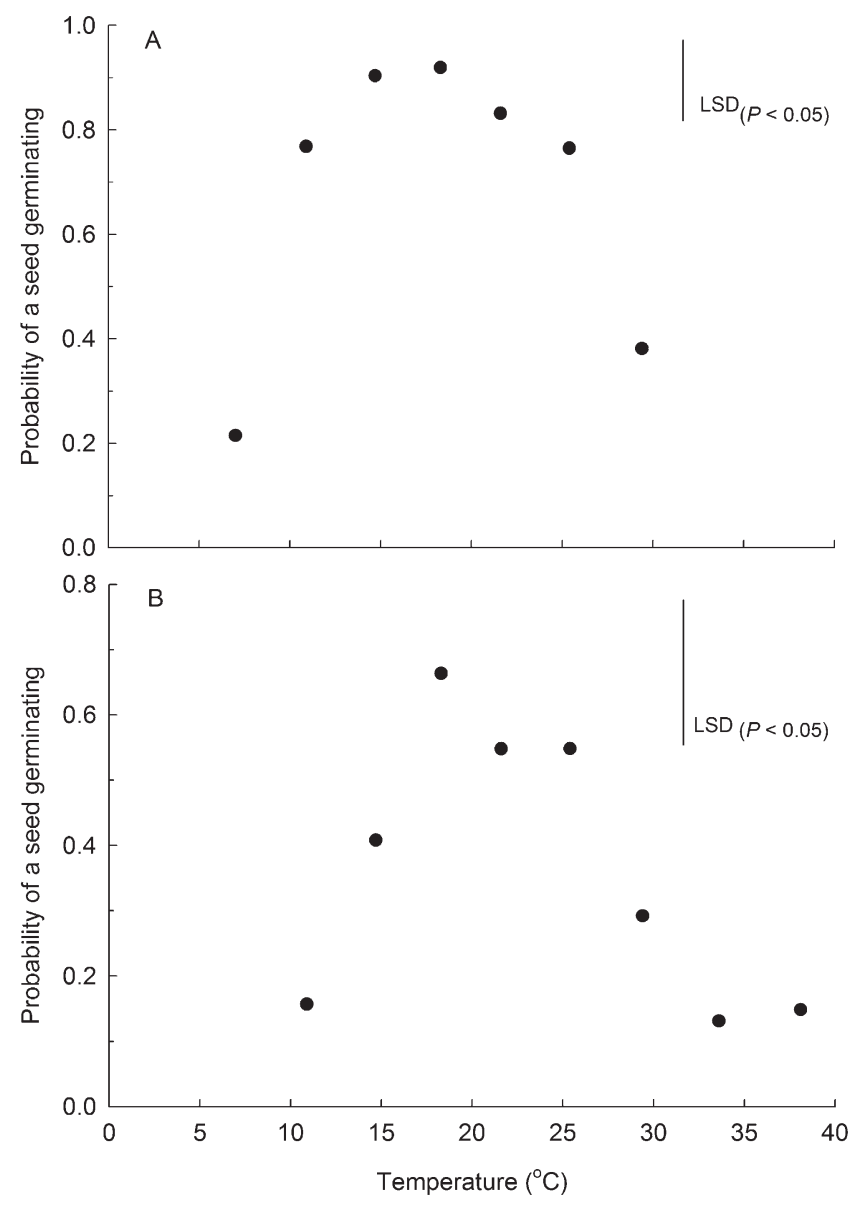

Fig. 2. Probability of a seed germinating after $31 \pm 0.5 \mathrm{~d}$ of incubation at substrate temperatures of 3 to $38{ }^{\circ} \mathrm{C}$ for Brunonia australis (A) and Calandrinia sp. (B).

34 and $38^{\circ} \mathrm{C}$. Seeds of both species that were incubated at 11 to $25^{\circ} \mathrm{C}$ showed germination levels of $1 \%$ or less after being transferred to $18{ }^{\circ} \mathrm{C}$. Most seeds that failed to germinate appeared to be viable, i.e., firm and not discolored.

Rate of seed germination. Plotting the reciprocal of time (days) taken to reach a given germination percentage $(G)$ against temperature showed mostly linear relationships for both species (Fig. 3A-B). For all values of $G$, the germination rate of $B$. australis increased markedly with rising temperature from a common base temperature of $5.1 \pm 0.3{ }^{\circ} \mathrm{C}$ and then peaked at an optimum temperature of $22.3 \pm 0.4{ }^{\circ} \mathrm{C}$ before decreasing linearly as temperatures rose in the supraoptimal range. The germination rate of $\mathrm{Cal}$ andrinia sp. increased linearly for $1 / t_{60}$ or less from a common base temperature of $6.3 \pm$ $0.4{ }^{\circ} \mathrm{C}$. For higher values of $G$, the rate began to plateau after reaching an optimum temperature, except for values at $38{ }^{\circ} \mathrm{C}$ that were omitted from analyses because they were obviously above the optimum for seed germination (Fig. 3B).

The time (days) taken for $50 \%$ of seeds to germinate and the delay between sowing and the onset of germination (lag) generally decreased as temperature rose (Table 1). $B$. australis showed a minimum requirement of $\approx 1.5 \mathrm{~d}$ for radicle emergence, whereas Cal- andrinia $\mathrm{sp}$. required at least $1 \mathrm{~d}$ for germination to start.

Cardinal temperatures and thermal time. A broken linear model (Eq. [3]) was used to describe the effect of temperature on reciprocal time to median germination $\left(1 / t_{50}\right)$ and percentage germination per day for $B$. aus tralis (Figs. 3A and 4A). Both germination rate indices gave similar estimated values for base $\left(T_{\mathrm{b}}\right)$ and optimum $\left(T_{\mathrm{o}}\right)$ temperatures (Table 2). However, the maximum temperature $\left(T_{\mathrm{m}}\right)$ for seed germination was clearly overestimated using the $1 / t_{50}$ index. Calandrinia $\mathrm{sp}$. showed a linear response for temperature versus $1 / t_{50}($ rate $=-0.059+0.010 \times$ temperature), whereas temperature versus percent germination per day was described using a broken linear response (Figs. 3B and 4B). Estimates of $T_{\mathrm{b}}$ were similar for both germination rate indices (Table 2). Optimum and maximum temperatures for seed germination were estimated using the percent germination per day index. Values of $38^{\circ} \mathrm{C}$ were omitted from analyses because they were clearly above the optimum for seed germination of Calandrinia sp. and inclusion would result in extrapolations for $T_{\mathrm{m}}$ that were outside biological limits for seed germination of most species.

Thermal times $\left({ }^{\circ} \mathrm{Cd}\right)$ for different percentages of seed germination $(G)$ are shown in Table 3. Values for B. australis were calculated 


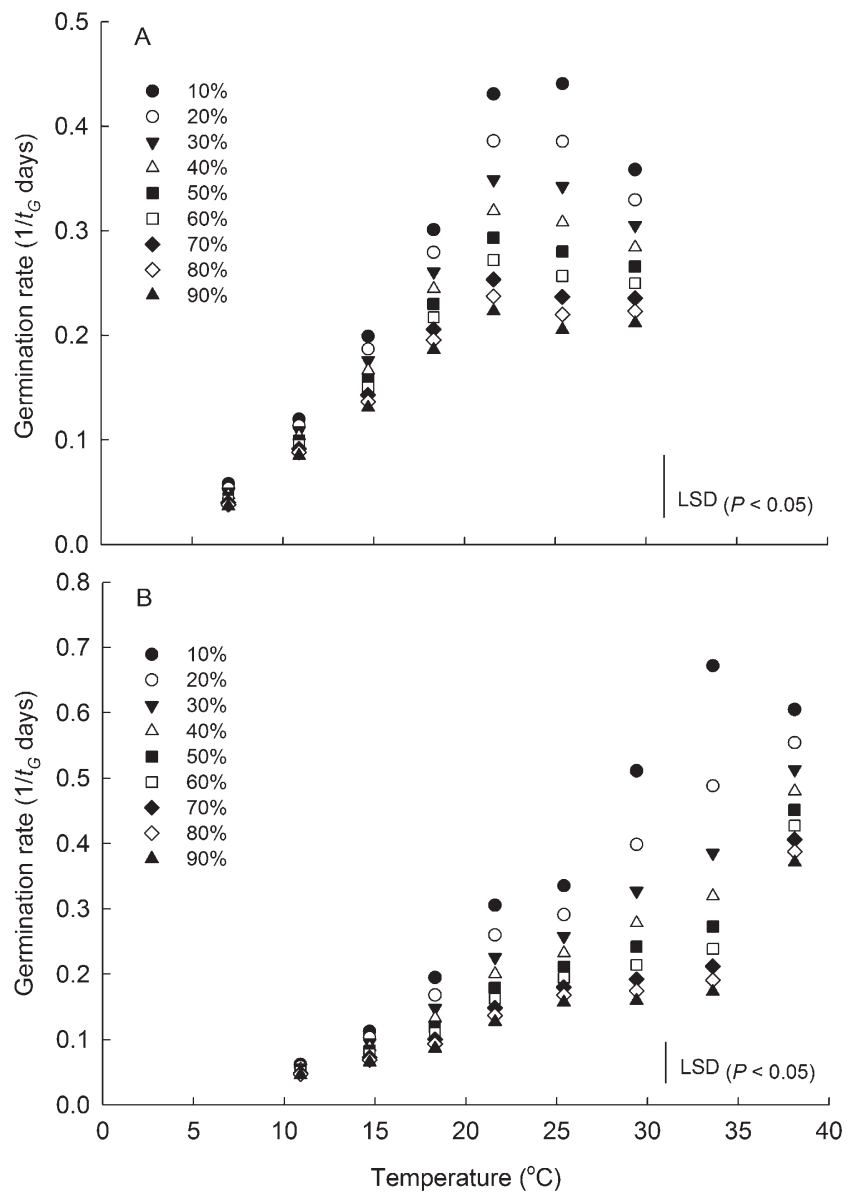

Fig. 3. Rate of seed germination, expressed as the reciprocal response time ( $t$, days) to reach a given percentage of total seed germination $(G)$ at substrate temperatures of 3 to $38^{\circ} \mathrm{C}$ for Brunonia australis (A) and Calandrinia sp. (B). Values for $38^{\circ} \mathrm{C}$ were omitted from analyses because they were clearly above the optimum for seed germination.

Table 1. Median response time ( $t_{50}$, days) and delay (lag, days) in the onset of seed germination at substrate temperatures of 7 to $38{ }^{\circ} \mathrm{C}$ for $B$. australis and Calandrinia sp.

\begin{tabular}{lcc}
\hline Temp $\left({ }^{\circ} \mathrm{C}\right)$ & $t_{50}($ days $)$ & Lag (days) \\
\hline B. australis & & \\
7 & $22.5(\mathrm{a})^{\mathrm{z}}$ & $11.2(\mathrm{a})$ \\
11 & $10.1(\mathrm{~b})$ & $6.3(\mathrm{~b})$ \\
15 & $6.3(\mathrm{c})$ & $3.8(\mathrm{bc})$ \\
18 & $4.3(\mathrm{~d})$ & $1.8(\mathrm{c})$ \\
22 & $3.5(\mathrm{~d})$ & $1.4(\mathrm{c})$ \\
25 & $3.6(\mathrm{~d})$ & $1.3(\mathrm{c})$ \\
29 & $3.8(\mathrm{~d})$ & $1.4(\mathrm{c})$ \\
& & \\
Calandrinia sp. & & \\
11 & $19.3(\mathrm{a})$ & $12.7(\mathrm{a})$ \\
15 & $12.3(\mathrm{~b})$ & $5.8(\mathrm{~b})$ \\
18 & $8.4(\mathrm{c})$ & $1.9(\mathrm{c})$ \\
22 & $5.6(\mathrm{~d})$ & $1.4(\mathrm{c})$ \\
25 & $4.7(\mathrm{~d})$ & $2.3(\mathrm{c})$ \\
29 & $4.1(\mathrm{de})$ & $1.1(\mathrm{c})$ \\
34 & $3.7(\mathrm{de})$ & $0.5(\mathrm{c})$ \\
38 & $2.2(\mathrm{e})$ & $1.4(\mathrm{c})$ \\
\hline
\end{tabular}

${ }^{2}$ Within a species and column, values followed by different letters are significantly different $(P<$ $0.05)$ according to probabilities for all pairwise comparisons.

using suboptimal temperatures (linear increase phase) and a $T_{\mathrm{b}}$ of $5.1{ }^{\circ} \mathrm{C}$, whereas ${ }^{\circ} \mathrm{Cd}$ for Calandrinia sp. were obtained using a $T_{\mathrm{b}}$ of $6.3^{\circ} \mathrm{C}$ and regimes of 11 to $25^{\circ} \mathrm{C}$ (temperatures above this range were excluded as a result of non-linearity). Both species showed ${ }^{\circ} \mathrm{Cd}$ to increase linearly with increasing percentage germination. Seeds of $B$. australis required 54 to $67^{\circ} \mathrm{Cd}$ for $50 \%$ to $90 \%$ germination and Calandrinia sp. accumulated 90 to $117{ }^{\circ} \mathrm{Cd}$ for the same percentage germination.

\section{Discussion}

Cardinal temperatures were obtained using seed germination rate indices that are typically used to determine germination responses of agricultural crops and weed species. This study appears to be the first published report that uses seed germination rate indices to investigate responses of Australian flora and could be suitable for developing other native plants. Both indices, reciprocal time to median germination (Eq. [1]) and percent germination per day (Eq. [2]), gave consistent estimates of base temperature that were biologically relevant and statistically robust (Table 2 ). The reciprocal time to median germination index was unsuitable for quantifying maximum temperature, whereas the percent germination per day index provided good estimates for all cardinal temperatures.

Uniform estimates for base temperature, and general linear responses for temperature versus reciprocal time taken to reach a given percentage germination, supported the use of thermal time to describe germination responses of B. australis and Calandrinia sp. Some studies suggest that species adapted to cooler temperatures have a lower base temperature and a higher thermal time requirement for seed germination (Trudgill et al., 2000). However, this relationship was not evident in the present study, because $B$. australis showed a lower base temperature and thermal time requirement, whereas Calandrinia sp. had a higher base temperature and greater thermal time requirement.

Both species appear well adapted for germination in cooler temperatures because they had relatively low base temperature estimates that were below or similar to the average minimum temperature for winter in their natural habitat (Table 2). Temperatures for optimum rate of germination and maximum seed germination of $B$. australis (Table 2; Fig. 2A) corresponded with cooler temperatures typically experienced in late fall to early spring for inland southern Queensland. Although rainfall in this region is generally lower during these seasons, mild temperatures reduce the rate of evaporation and soil water is more likely to be retained long enough for seedlings to become established, whereas moisture from summer rainfall can quickly evaporate. Similarly, temperatures for optimum germination rate and maximum germination of Calandrinia sp. seeds (Table 2; Fig. 2B) coincided with cooler temperatures in late fall and early spring in the plant's natural habitat: the Gascoyne region of Western Australia. However, the average monthly rainfall in early spring is $\approx 5$ $\mathrm{mm}$, whereas rainfall for late fall is 15 to 25 $\mathrm{mm}$, suggesting that natural seed germination would take place during late fall when the soil moisture content was higher. Interestingly, some seeds showed rapid germination at 29 to $38^{\circ} \mathrm{C}$ and this is comparable to temperatures experienced during summer in the Gascoyne region. It is possible that some seeds may germinate under hot conditions, particularly in microhabitats where soil moisture is retained for longer periods. Flowering of these plants most likely would be delayed, because studies have shown that temperatures below $20{ }^{\circ} \mathrm{C}$ are required to hasten flower bud production (Cave et al., 2010).

Generally, high temperatures of 34 and $38^{\circ} \mathrm{C}$ were unfavorable for seed germination because maximum germination percentage was low. This response is common for many Australian native plants with the exception of some species within the family Casuarinaceae and Poaceae that germinate readily at $35{ }^{\circ} \mathrm{C}$ (Bell, 1999). High temperatures are thought to reinforce or induce seed dormancy to prevent germination during conditions unfavorable for seeding survival by strengthening the endosperm or pericarp and creating a physical barrier that is impervious to the radicle (Bell, 1999; Bell et al., 1993). On return to cooler temperatures, seeds of some species may germinate, but germination percentages are likely to be reduced as a result of seed death caused by exposure to high 

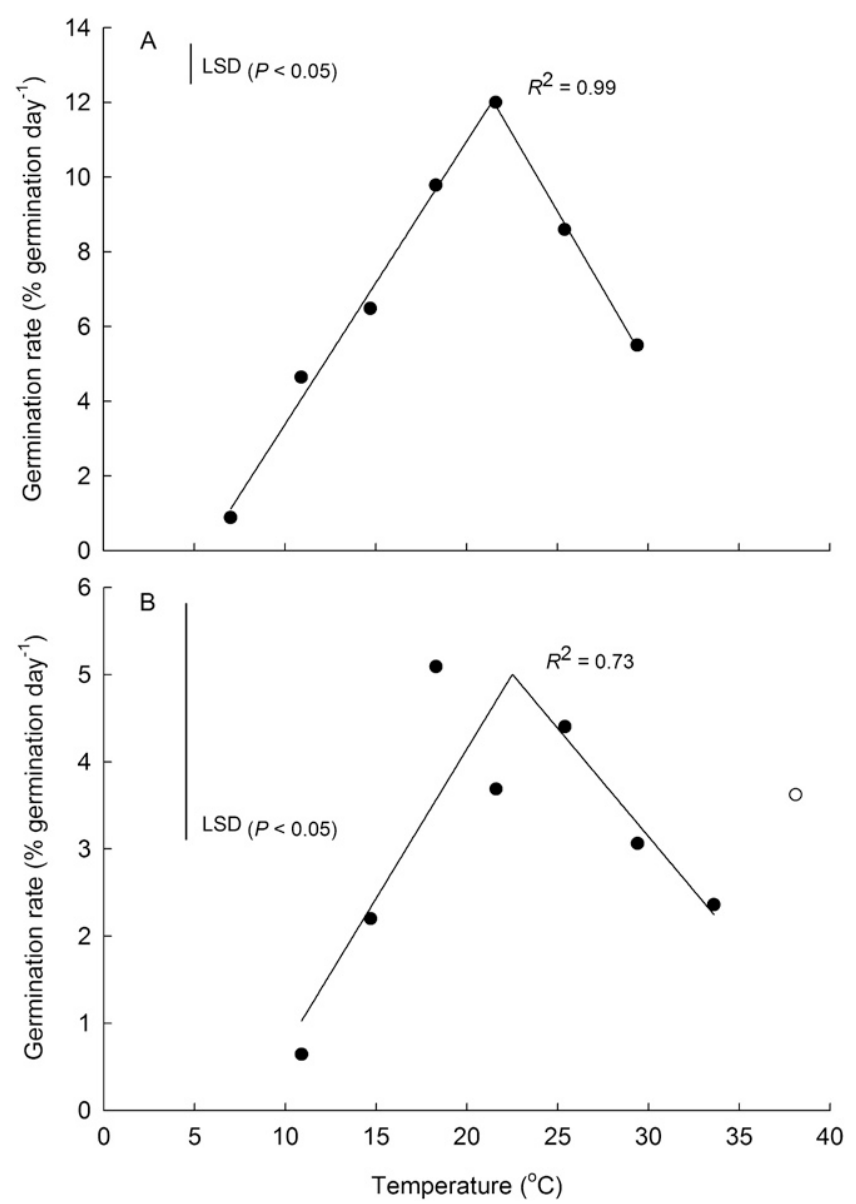

Fig. 4. Rate of seed germination, expressed as percentage seed germination per day, at substrate temperatures of 7 to $38{ }^{\circ} \mathrm{C}$ for Brunonia australis (A) and Calandrinia sp. (B). The relationship between temperature and germination rate was described using a broken linear function (Eq. [3]). Values for $38{ }^{\circ} \mathrm{C}$ (open circle) were omitted from analyses because they were clearly above the optimum for seed germination.

Table 2. Estimates of base $\left(T_{\mathrm{b}}\right)$, optimum $\left(T_{\mathrm{o}}\right)$ and maximum temperature $\left(T_{\mathrm{m}}\right)$, and optimum germination rate $\left(R_{\mathrm{opt}}\right)$ for seeds of $B$. australis and Calandrinia sp. calculated using two germination rate indices: reciprocal time to median germination $\left(1 / t_{50}\right)$ and percentage germination per day ( $\%$ germination/day) ${ }^{z}$

\begin{tabular}{lcc}
\hline & \multicolumn{2}{c}{ Index } \\
\cline { 2 - 3 } & $1 / t_{50} \%$ germination/day \\
\hline B. australis & 4.9 & 5.5 \\
$T_{\mathrm{b}}\left({ }^{\circ} \mathrm{C}\right)$ & 21.9 & 21.4 \\
$T_{\mathrm{o}}\left({ }^{\circ} \mathrm{C}\right)$ & 103.5 & 35.9 \\
$T_{\mathrm{m}}\left({ }^{\circ} \mathrm{C}\right)$ & 0.2926 & 12.05 \\
$R_{\mathrm{opt}}$ & 0.9958 & 0.9920 \\
$R^{2}$ & & \\
& & \\
Calandrinia sp. & 5.8 & 7.9 \\
$T_{\mathrm{b}}\left({ }^{\circ} \mathrm{C}\right)$ & $\mathrm{NA}$ & 22.5 \\
$T_{\mathrm{o}}\left({ }^{\circ} \mathrm{C}\right)$ & $\mathrm{NA}$ & 42.7 \\
$T_{\mathrm{m}}\left({ }^{\circ} \mathrm{C}\right)$ & $\mathrm{NA}$ & 5.0 \\
$R_{\mathrm{opt}}$ & 0.9831 & 0.7322 \\
$R^{2}$ &
\end{tabular}

${ }^{2}$ Values of $R^{2}$ are included.

$\mathrm{NA}=$ not applicable.

temperatures (Bellairs and Bell, 1990). Likewise, few seeds of $B$. australis and Calandrinia sp. germinated when transferred to $18^{\circ} \mathrm{C}$ after $31 \mathrm{~d}$ of moist incubation at 34 and $38^{\circ} \mathrm{C}$.
Table 3. Estimates of thermal time $\left({ }^{\circ} \mathrm{Cd}\right)$ for different germination percentages $(G)$ of $B$. australis and Calandrinia sp. $^{\text {. }}$

\begin{tabular}{lcc}
\hline & \multicolumn{2}{c}{ Thermal time $\left({ }^{\circ} \mathrm{Cd}\right)$} \\
\cline { 2 - 3 } $\mathrm{G}$ & B. australis & Calandrinia sp. \\
\hline 10 & 42.0 & 61.5 \\
20 & 45.1 & 68.5 \\
30 & 48.2 & 75.5 \\
40 & 51.3 & 82.6 \\
50 & 54.4 & 89.6 \\
60 & 57.5 & 96.6 \\
70 & 60.6 & 103.7 \\
80 & 63.7 & 110.7 \\
90 & 66.8 & 117.7 \\
\hline zThermal & times for $B$ australis were calculated
\end{tabular}

${ }^{2}$ Thermal times for $B$. australis were calculated using a common $T_{\mathrm{b}}$ of $5.1{ }^{\circ} \mathrm{C}$ and values from 7 to $22{ }^{\circ} \mathrm{C}$ (suboptimal range). A common $T_{\mathrm{b}}$ of $6.3^{\circ} \mathrm{C}$ and data obtained for 11 to $25^{\circ} \mathrm{C}$ were used to compute ${ }^{\circ} \mathrm{Cd}$ for Calandrinia sp.

Seeds that failed to germinate at high temperatures appeared viable. However, it is likely these seeds were dead given that ample time was allowed for germination to occur after transfer to favorable conditions and the inherent subjective interpretation of seed viability when using the cut method on small seeds (Gosling, 2003). Seed death caused by moist incubation at $35^{\circ} \mathrm{C}$ has been reported in a number of Australian native species, including Velleia trinervis that belongs to the family Goodeniaceae (Bellairs and Bell, 1990). Loss of viability may be the result of increases in cell membrane permeability and the ensuing loss of $\mathrm{K}^{+}$and total electrolytes (Corbineau et al., 2002). In contrast, approximately half of the seeds of $B$. australis and Calandrinia sp. that were incubated for $31 \mathrm{~d}$ below the estimated base temperature germinated after being transferred to $18^{\circ} \mathrm{C}$, which suggested that cold temperatures can cause seed dormancy in these species.

Although both species germinated readily in the present study under favorable conditions, reports indicate that physiological dormancy may be present in fresh seeds (Roche et al., 1997; R.L. Cave, unpublished data). Physiological dormancy, a condition mainly controlled by factors within the embryo, can be alleviated using pre-treatments such as cold stratification, mechanical and chemical scarification, and dry after-ripening (Baskin and Baskin, 1998, 2004). Seeds used in this study were stored dry at $10{ }^{\circ} \mathrm{C}$ for $\approx 4.5$ years and may explain why seed dormancy was not observed. Given this information, it is reasonable to infer that pre-treatment may be necessary to break dormancy.

\section{Conclusion}

Both germination rate indices, reciprocal time to median germination and percent germination per day, gave consistent estimates of base temperature for both species, whereas the percent germination per day index provided biologically relevant estimates for base, optimum, and maximum temperatures. Seed germination of B. australis and Calandrinia sp. appeared well adapted to cooler temperatures with base temperature estimates of 4.9 and $5.5^{\circ} \mathrm{C}$ and 5.8 and $7.9^{\circ} \mathrm{C}$, respectively. Thermal time $\left({ }^{\circ} \mathrm{Cd}\right)$ increased with increasing percentage germination. B. australis required $54{ }^{\circ} \mathrm{Cd}$ and Calandrinia sp. $90{ }^{\circ} \mathrm{Cd}$ for $50 \%$ of the seed population to germinate.

\section{Literature Cited}

Baskin, C.C. and J.M. Baskin. 1998. Seeds: Ecology, biogeography, and evolution of dormancy and germination. Academic Press, San Diego, CA.

Baskin, J.M. and C.C. Baskin. 2004. A classification system for seed dormancy. Seed Sci. Res. 14:1-16.

Bell, D.T. 1999. The process of germination in Australian species. Aust. J. Bot. 47:475-517.

Bell, D.T., J.A. Plummer, and S.K. Taylor. 1993. Seed germination ecology in southwestern Western Australia. Bot. Rev. 59:24-73.

Bellairs, S.M. and D.T. Bell. 1990. Temperature effects on the seed germination of ten Kwongan species from Eneabba, Western Australia. Aust. J. Bot. 38:451-458.

Bureau of Meteorology. 2010a. Climate statistics for Australian locations. Australian Government, Melbourne, 6 May 2010. <http://www. bom.gov.au/climate/averages/tables/cw_046064. shtml>. 
Bureau of Meteorology. 2010b. Climate statistics for Australian locations. Australian Government, Melbourne. 6 May 2010. <http://www.bom.gov. au/climate/averages/tables/cw_007161.shtml>.

Carolin, R.C. 1992. Brunoniaceae, p. 1-3. In: George, A.S. (ed.). Flora of Australia. Vol. 35. Australian Government Publishing Service, Canberra, Australia.

Cave, R.L., C.J. Birch, G.L. Hammer, J.E. Erwin, and M.E. Johnston. 2010. Floral ontogeny of Brunonia australis (Goodeniaceae) and Calandrinia sp. (Portulacaceae). Aust. J. Bot. 58:61-69.

Corbineau, F., C. Gay-Mathieu, D. Vinel, and D. Côme. 2002. Decrease in sunflower (Helianthus annuus) seed viability caused by high temperature as related to energy metabolism, membrane damage and lipid composition. Physiol. Plant. 116:489-496.

Garcia-Huidobro, J., J.L. Monteith, and G.R Squire. 1982. Time, temperature and germination of pearl millet (Pennisetum typhoides S \&
H). I. Constant temperature. J. Expt. Bot. 33: 288-296.

Gosling, P.G. 2003. Viability testing, p. 446-481. In: Smith, R.D., J.B. Dickie, S.H. Linington, H.W. Pritchard, and R.J. Probert (eds.). Seed conservation: Turning science into practice. Royal Botanic Gardens, Kew, London, UK.

Harrison, D.K., P. Wickramasinghe, M.E. Johnston, and D.J. Joyce. 2009. Evaluating mutation breeding methods to fast-track the domestication of two Australian native Calandrinia species for ornamental horticulture. Acta Hort. 829:85-90.

Holt, J.S. and D.R. Orcutt. 1996. Temperature thresholds for bud sprouting in perennial weeds and seed germination in cotton. Weed Sci. 44:523-533.

Mayer, A.M. and I. Marbach. 1981. Biochemistry of the transition from resting to germinating state in seeds. Prog. in Phytochem. 7:95-136.

Mayer, A.M. and A. Poljakoff-Mayber. 1989. The germination of seeds. 4th Ed. Pergamon Press, Oxford, UK
O'Neil, M.E., P.C. Thomson, B.C. Jacobs, P Brain, R.C. Butler, H. Turner, and B. Mitakda. 2004. Fitting and comparing seed germination models with a focus on the inverse normal distribution. Aust. N. Z. J. Stat. 46:349-366.

Roche, S., K.W. Dixon, and J.S. Pate. 1997. Seed ageing and smoke: Partner cues in the amelioration of seed dormancy in selected Australian native species. Aust. J. Bot. 45:783-815.

Slafer, G.A. and R. Savin. 1991. Developmental base temperature in different phenological phases of wheat (Triticum aestivum). J. Expt. Bot. 42:1077-1082.

Stanley, T.D. and E.M. Ross. 1986. Flora of southeastern Queensland. Vol. 2. Queensland Department of Primary Industries, Brisbane, Australia.

Trudgill, D.L., G.R. Squire, and K. Thompson. 2000. A thermal time basis for comparing the germination requirements of some British herbaceous plants. New Phytol. 145:107-114. 